\title{
CHARACTERIZATION OF FOOD BARS MANUFACTURED WITH AGROINDUSTRIAL BY-PRODUCTS AND WASTE
}

\section{Caracterização de barras alimentícias elaboradas com subprodutos e resíduos agroindustriais}

\author{
Andréa Paolucci Paiva ${ }^{1}$, Maria de Fátima Píccolo Barcelos ${ }^{2}$, \\ Juciane de Abreu Ribeiro Pereira ${ }^{3}$, Eric Batista Ferreira ${ }^{4}$, Sueli Ciabotti ${ }^{5}$
}

\begin{abstract}
Food bars are products obtained from the union of a number of components, standing out in the snack category due to their portability attribute with a focus on convenience and health. Utilization of by-products and agroindustrial food waste as ingredients in the making of food bars is highly important due to the utilization of leftovers of marked nutritional and functional value and decrease of the production cost. This work intended to evaluate the chemical and physicochemical aspects of food bars made with the by-products broken rice (BR) and pequi nut (PN), soybean extract residue (SER), and pineapple waste (PW). Distinct proportions of BR: SER respectively were used, amounting to five treatments: 1:0 (A); 3:1 (B); 1:1 (C); 1:3 (D) and 0:1(E) and fixed amounts of the other components. For the statistical analysis, variance analysis and the Tukey test were performed to 5\% significance. The moisture, protein, lipid, ash, mineral, and dietary fiber contents were directly increased as the SER was increased and the amount of $\mathrm{BR}$ was decreased. However, the opposite was found with both carbohydrates and calories. The soluble solids, $\mathrm{pH}$ and water activity values presented increases with the increased soybean extract residue. All the treatments presented slightly acidic $\mathrm{pH}$ and water activity bellow 0.6, favoring microbiological safety. In the chemical score, treatment A presented lysine as the limiting aminoacid in relation to the Food and Agriculture Organization - FAO/WHO reference (1990). The food bars can be considered rich in dietary fiber and with considerable nutritional support. Treatments D and E proved better in the set of the variables studied for human consumption.
\end{abstract}

Index terms: Soybean residue extract, pequi nut, broken rice, pineapple waste.

\section{RESUMO}

Barras alimentícias são produtos obtidos a partir da junção de vários componentes, destacando-se na categoria dos snacks em razão do atributo portabilidade com foco em conveniência e saúde. A utilização de subprodutos e de resíduos agroindustriais alimentícios como ingredientes na elaboração de barras alimentícias têm grande importância em decorrencia do aproveitamento de remanescentes de considerado valor nutricional e funcional e diminuição do custo de produção. No trabalho, objetivou-se avaliar aspectos químicos e físico-químicos de barras alimentícias elaboradas com subprodutos quirera de arroz (QR) e castanha de pequi (CP), resíduo de extrato de soja (RES) e resíduo de abacaxi (RA). Utilizaram-se proporções distintas de QA: RES totalizando cinco tratamentos: 1:0 (A); 3:1 (B); 1:1 (C); 1:3 (D) e 0:1(E) e quantidades fixas dos demais componentes. Para análise estatística foram realizadas análise de variância e teste de Tukey, a 5\% de significância. Os teores de umidade, proteínas, lipídeos, cinzas, minerais e de fibra alimentar foram estritamente crescentes à medida que aumentava-se o RES e diminuía-se a quantidade de QA. Já, com carboidratos e calorias, observou-se o inverso. Os valores de sólidos solúveis, $\mathrm{pH}$ e atividade da água, apresentaram-se crescentes com o aumento de resíduo do extrato de soja. Todos os tratamentos apresentaram $\mathrm{pH}$ levemente ácido e atividade da água abaixo de 0,6, podendo favorecer a segurança microbiológica. No escore químico, o tratamento A apresentou a lisina como aminoácido limitante em relação à referência da FAO/WHO (1990). As barras alimentícias podem ser conideradas ricas em fibra alimentar e com considerável aporte nutricional. Os tratamentos D e E apresentaram-se melhores no conjunto das variáveis analisadas para o consumo humano.

Termos para indexação: Resíduo do extrato de soja, castanha de pequi, quirera de arroz, resíduo de abacaxi.

(Received in april 3, 2012 and approved in may 8, 2012)

\section{INTRODUCTION}

Routinely, new food products are released in the world market, with fast meal characteristics in the category of snacks, light and nutritive small meals such as extruded biscuits, breakfast cereals, granolas and cereal bars. These products, in addition to consumption practicality, meet a considerable part of the daily nutrient requirements of the individuals (MITCHELL; BOUSTAIN, 1990; TETTWEILER, 1991; PENNA; TUDESCA, 2001; FREITAS; MORETTI, 2006). In this line, the obtaining of food products of high nutritive value with of functional and low

IInstituto Federal Sudeste de Minas Gerais - Campus Barbacena - Barbacena - MG - Brasil

2Universidade Federal de Lavras/UFLA - Departamento de Ciência dos Alimentos/DCA - Lavras - MG - Brasil

${ }^{3}$ Instituto Federal/IF - Sudeste de Minas Gerais - Campus Barbacena - São José-36205-018-Barbacena-MG - Brasil - juciane.ribeiro@ifsudestemg.edu.br

${ }^{4}$ Universidade Federal de Alfenas/UNIFAL - Departamento Ciências Exatas - Alfenas - MG - Brasil

${ }^{5}$ Instituto Federal Sudeste de Minas Gerais - Departamento de Ciência dos Alimentos - Uberaba - MG - Brasil 
cost characteristics has been a focus of studies in recent years.

The plant food agroindustries, parallel to the conventional line of their products, generate by-products and waste, which maintain considerable nutritive and fiber potential besides a quite agreeable flavor. However, much in natura agroindustrial waste cannot be consumed as such, having to be mechanically and/or thermally processed ensuring microbiological and nutritional quality, which favors consumption (GIUNTINI et al., 2003; EVANGELISTA, 2005). In addition, the waste has been the cause of great concern for the industry, because when they are not used for animal feeding or utilized as fertilizer, they are discarded in the open or in rivers, polluting the environment (SOUZA; SANTOS, 2002; GIUNTINI et al., 2003; EVANGELISTA, 2005). In the making of pineapple jams, candied fruit and juice, removing and discarding the core of that fruit is a usual practice, a fact that also occurs with the pequi nut; these wastes being, the majority of time, unutilized.

The combination of thermally-processed cereals and legumes is recognized by the improved quality of proteins in plant foods (BAKAR; HIN, 1984; FERNANDES et al., 2000; MAIA et al., 2000).

The verification of the viability of using the agroindustrial by-products and waste with the added value to be used in human feeding has been constantly investigated by several authors (BOTELHO et al., 2002; GIUNTINI et al., 2003; BORGES et al., 2004; BALESTRO et al., 2011). The making of food bars by utilizing proportions of plant agroindustrial by-products and waste can be an interesting alternative and makes the establishment of wholesome feeding practices viable.

In that context, the objective of the present work was to evaluate, under chemical, physical and nutritional aspects, food bars made with agroindustrial by-products (broken rice $\mathrm{BR}$ and pequi nut $\mathrm{PN}$ ) and waste (soybean extract residue, SER and pineapple waste $\mathrm{PW}$ ).

\section{MATERIAL AND METHODS}

\section{Making of the food bars}

Previous chemical analyses of the ingredients was conducted aiming to define their proportions in the elaboration of food bars in order that that a portion $(25 \mathrm{~g}$ food bar unit) meets from 3 to $5 \%$ of the protein requirement of an adult man $(70 \mathrm{~kg})$ defined by the Estimated Average Requirement, EAR (INSTITUTE OF MEDICINE - IOM, 2005) and that the bar would be characterized as a source of dietary fiber (AGÊNCIA NACIONALDE VIGILÂNCIASANITÁRIA-ANVISA, 1998).

The food bars were manufactured with solid (50\%) and moist $(50 \%)$ ingredients. The solid phase was made up of ingredients in varying amounts of the cereal (rice), in the form of the by-product broken rice, BR, combined with the legume residue (soybean) soybean extract residue, SER, (both amounting to 24\%) and with ingredients in fixed amounts of pequi nut (PN) $4 \%$ and pineapple waste (PW) $12 \%$, (both amounting to $26 \%$ ) (Table 1 ).

Table 1 - Components of the food bars.

\begin{tabular}{llccccc}
\hline & & \multicolumn{4}{c}{ Food Bars } \\
\cline { 3 - 6 } & Ingredients & \multicolumn{3}{c}{ Ingredients (\%) } \\
& & $\mathrm{A}$ & $\mathrm{B}$ & $\mathrm{C}$ & $\mathrm{D}$ & $\mathrm{E}$ \\
\hline \multirow{3}{*}{ Solid ingredients } & broken rice (BR) & 24 & 18 & 12 & 6 & 0 \\
& soybean extract residue (SER) & 0 & 6 & 12 & 18 & 24 \\
& pequi nut (PN) & 4 & 4 & 4 & 4 & 4 \\
& pineapple waste (PW) & 12 & 12 & 12 & 12 & 12 \\
\hline & glucose syrup & 23 & 23 & 23 & 23 & 23 \\
& sugarcane molasses & 22 & 22 & 22 & 22 & 22 \\
& inverted sugar & 2 & 2 & 2 & 2 & 2 \\
& bi-distilled glycerin & 0.75 & 0.75 & 0.75 & 0.75 & 0.75 \\
& sunflower oil & 1.5 & 1.5 & 1.5 & 1.5 & 1.5 \\
& citric pectin & 0.5 & 0.5 & 0.5 & 0.5 & 0.5 \\
& Salt & 0.25 & 0.25 & 0.25 & 0.25 & 0.25 \\
\hline
\end{tabular}

Legend: Proportions of BR: SER were established, namely, 1:0 (A), 3:1 (B), 1:1 (C), 1:3 (D) and 0:1(E).

Ciênc. agrotec., Lavras, v. 36, n. 3, p. 333-340, maio/jun., 2012 
Five treatments for the two food bars with different proportions of BR: SER were established, namely, 1:0 (A), 3:1 (B), 1:1 (C), 1:3 (D) and 0:1(E).

The broken rice utilized in this work was of mixed rice varieties (Oryza sativa L.) (from a local rice processing firm in the town of Lavras, MG and the soybean [Glycine $\max ($ L.) Merrill] BRS Garantia, originated from Empresa de Pesquisa Agropecuária de Minas Gerais, EPAMIG/Uberaba (Minas Gerais Agricultural Research Corporation, EPAMIG/UBERABA). The broken rice was cooked (pregelatinized) and afterwards dehydrated. The pequi nut, Caryocar brasiliense Cambess, was acquired from a family farm in the town of Taiobeiras, northern Minas Gerais, and the pineapple juice residue and dehydrated preserve residue from CEFET-Uberaba.

Table 1 shows the composition of the food bars.

The other $50 \%$, the moist ingredients which made up the binder syrup were glucose syrup $\left(60^{\circ}\right.$ Brix $)(23 \%)$, sugarcane molasses $\left(76^{\circ} \mathrm{Brix}\right)(22 \%)$, inverted sugar $\left(77.8^{\circ}\right.$ Brix) $(2 \%)$, bi-distilled glycerin $(0.75 \%)$, sunflower oil $(1.5 \%)$, citric pectin $(0.5 \%)$ and salt $(0.25 \%)$, hated to a temperature of $95^{\circ} \mathrm{C}\left(85^{\circ}-86^{\circ} \mathrm{Brix}\right)$.

The solid ingredients and the components of the binder syrups were mixed for agglutination and homogenization under heating for 30 seconds, resulting in ingredient uniformity. The mass obtained was rolled by means of pressure with a roller, cooled to room temperature, cut in rectangular shaped bars $(9.00 \mathrm{~cm} \times 3.00 \mathrm{~cm} \times 0.60 \mathrm{~cm})$ of about $25 \mathrm{~g}$ each and wrapped with aluminum foil and in polyethylene packages appropriate for foods (GOMES; MONTENEGRO, 2006 com adaptations).

\section{Centesimal composition and caloric value}

The centesimal composition of the food bars under study was performed according to the Association of Official Analytical Chemists - AOAC (1997). Carbohydrates were quantified by difference, considering total dietary fiber, which was determined by the gravimetric enzymatic method according to the AOAC (1997) and Prosky et al. (1998) with modifications.

The caloric value was calculated on the basis of the composition of the food bars, the Atawater conversion factors of $4 \mathrm{kcal} / \mathrm{g}$ (protein), $4 \mathrm{kcal} / \mathrm{g}$ (carbohydrates) and 9 $\mathrm{kcal} / \mathrm{g}$ (lipids), according to Osborne and Voogt (1978).

\section{Determination of the food bars}

Analyses of minerals (P, K, Mg, S, Cu, Mn, $\mathrm{Zn}$ and Fe) were performed from extract of the samples by nitro-perchloric digestion and determined according to Malavolta et al. (1989).

\section{Analysis of aminoacids (aminogram)}

The aminograms were performed by high performance liquid chromatography (HPLC). Acidic hydrolysis in the samples with $\mathrm{HCl} 6 \mathrm{~N}$ (SPACKMAN et al., 1958) was applied. For the determination of tryptophan, $\mathrm{LiOH} 4 \mathrm{~N}$ was applied for 24 hours at $110 \pm 1^{\circ} \mathrm{C}$ (LUCAS; SOTELO, 1980) by means of HPLC in cation exchange resin columns in a Nicolas $\mathrm{V}$ aminoacid analyzer.

Aliquots between 0.010 and $0.900 \mathrm{~mL}$ were applied in the cation exchange columns (resin: $\mathrm{PC} 6 \mathrm{a}$ amino acid analysis resin, Pierce) and eluted by differences of $\mathrm{pH}$ and ionic strength (short column pH5.28; long column pH3.25 and, later, $\mathrm{pH} 4.25$ ) (SPACKMANet al., 1958). After the chromatographic separation, the aminoacids eluted from the column reacted with ninhydrin and the products of this reaction were colorimetrically detected at two wavelengths: $440 \mathrm{~nm}$ for proline $(6 \mathrm{~mm}$ path length cuvette) and $570 \mathrm{~nm}$ for the aminoacids (12 $\mathrm{mm}$ path length cuvette). The identification of the peaks was done on the basis of the retention times of each residue.

\section{Chemical score}

The chemical score of aminoacids (CS) was carried out according to Pellet and Young (1980), taking the Food and Agriculture Organization/World Health Organization FAO/WHO (1990) theoretical standard as the reference for identification of limiting aminoacids in the products.

\section{Physicochemical analyses of the food bars}

For the determination of $\mathrm{pH}$ of the food bar samples studied, the Schott Handylab (digital) pHmeter was used, in homogenized product solution with distilled water according to the AOAC (1997).

The soluble solids content were determined by reading in hand-held refractometer, Atago, model N-1E with ${ }^{\circ}$ BRIX, between 0 and $32 \%$, according to AOAC (1990).

Water activity (Aw) was measured by the Aqua $\mathrm{Lab}^{\circledR}$ apparatus, with Aw standard of 0.492 at a temperature of $25^{\circ} \mathrm{C}$ with determination of the dewpoint by the chilled mirror technique.

\section{Statistical analysis}

The experimental design of the technological, chemical and biochemical analyses was completely randomized with five treatments and four replicates.

The effects of treatments were evaluated by variance analysis (ANAVA), followed by the Tukey test at $5 \%$ of significance to identify the differences in significant cases. The variance analyses and the means test were performed in the Sisvar ${ }^{\circledR}$ software. 


\section{RESULTSAND DISCUSSION}

\section{Centesimal composition and minerals}

Table 2 shows the centesimal composition and caloric value of the food bars.

The five food bar treatments presented significant differences $(\mathrm{p}<0.05)$ in the centesimal composition, demonstrating strictly increasing behavior from treatment A to treatment E, for protein, lipids, dietary fiber (total, insoluble and soluble) and ash and also decreasing from treatment A to treatment $\mathrm{E}$ for carbohydrates and calories. This is because the difference among the treatments are the BR and SER proportions, the latter ingredient being richer in proteins, lipids and dietary fibers, although with low carbohydrate content when compared with BR.

A food bar (25g) manufactured according to Treatment A furnishes $2.03 \mathrm{~g}$ of protein and Treatment $\mathrm{E}$ furnishes, in turn, $3.11 \mathrm{~g}$ of protein. These protein contents meet $4.39 \%$ and $6.73 \%$ of EAR, respectively, considering that the daily requirement of a male adult $(70 \mathrm{~kg})$ is $46.2 \mathrm{~g}$ of protein/day (IOM, 2005).

In relation to the dietary fiber content, the food bars presented from $11.61 \%$ (Treatment A) to $21.19 \%$ (Treatment E) conformity to the Dietary Reference Intake (DRI) of this constituent (IOM, 2005) which is 25g fiber/ day intake. So, the five types of food bars ( $25 \mathrm{~g}$ each) can be considered "source of dietary fiber", according to the ANVISA (1998), for presenting contents of between $3 g$ and $5 \mathrm{~g}$ of dietary fiber per portion of the consumptionready product.
The moisture contents of treatments B, C, D and E did not differ from one another, but they were higher than treatment A which is made up of BR and other fixed ingredients without the presence of the SER which conferred higher moisture content to all the other food bars. However, all the treatments presented moisture inferior to $15 \%$ which is established by the legislation (BRASIL, 2005).

The chemical components of certain food bars of this study were similar to the contents found in the study by Freitas (2005), who characterized cereal bars based on textured soy protein, oats and wheat germ, with an average content of $10.71 \%$ moisture, $15.31 \%$ protein, $2.20 \%$ ash and $60.97 \%$ of glicidic fraction.

The mean lipid values of the food bars investigated ranged from $6.72 \%$ to $9.98 \%$ (Table 2), content higher than that found by Baú et al. (2010) of $2.23 \%$ when analyzing food bar with high protein content and low lipid content. However, the importance of the lipid content of the bars of the present work, for the supply of polyunsaturated fatty acids, derived mainly from sunflower oil and pequi nut is stressed. The mineral contents ( $\mathrm{P}, \mathrm{K}, \mathrm{Mg}, \mathrm{S}, \mathrm{Cu}, \mathrm{Mn}, \mathrm{Zn}$ and $\mathrm{Fe}$ ) of the food bars (Table 3) presented significant differences $(\mathrm{p}<0.05)$ among the studied treatments.

Treatment E presented higher values of $\mathrm{P}, \mathrm{K}, \mathrm{Mg}$ and $\mathrm{Fe}$ in relation to the other treatments. Treatments $\mathrm{D}$ and $\mathrm{E}$ were superior as to the minerals $\mathrm{Cu}$ and $\mathrm{Zn}$; treatments $\mathrm{C}, \mathrm{D}$ and $\mathrm{E}$ presented equal values of $\mathrm{S}$ and all the treatments presented no differences among the values of $\mathrm{Mn}(\mathrm{p}<0.05)$.

Table 2 - Average values of the centesimal composition (\%) and calories (kcal) of the food bars elaborated with byproducts (broken rice, BR and pequi nut, PN) and agroindustrial waste (soybean extract residue, SER and pineapple waste, PW) with fixed amounts of PN and PW and at different BR:SER proportions.

\begin{tabular}{|c|c|c|c|c|c|}
\hline \multirow{2}{*}{$\begin{array}{c}\text { Investigated } \\
\text { variables }\end{array}$} & \multicolumn{5}{|c|}{ Food bars BR:SER } \\
\hline & $1: 0(\mathrm{~A})$ & $3: 1(\mathrm{~B})$ & $1: 1(\mathrm{C})$ & $1: 3$ (D) & $0: 1(\mathrm{E})$ \\
\hline Moisture & $9.44^{\mathrm{b}} \pm 0.21$ & $11.59^{\mathrm{a}} \pm 0.18$ & $11.70^{\mathrm{a}} \pm 0.20$ & $11.58^{\mathrm{a}} \pm 0.29$ & $11.54^{\mathrm{a}} \pm 0.35$ \\
\hline Protein & $8.12^{\mathrm{e}} \pm 0.13$ & $9.89^{\mathrm{d}} \pm 0.11$ & $10.84^{\mathrm{c}} \pm 0.29$ & $11.63^{\mathrm{b}} \pm 0.17$ & $12.43^{\mathrm{a}} \pm 0.39$ \\
\hline Lipíds & $6.72^{\mathrm{e}} \pm 0.15$ & $7.38^{\mathrm{d}} \pm 0.24$ & $8.58^{\mathrm{c}} \pm 0.19$ & $9.04^{\mathrm{b}} \pm 0.25$ & $9.98^{\mathrm{a} \pm 0.16}$ \\
\hline $\mathrm{TDF}^{*}$ & $11.61^{\mathrm{d}} \pm 0.57$ & $12.72^{\mathrm{d}} \pm 0.37$ & $15.17^{\mathrm{c}} \pm 1.38$ & $17.92^{\mathrm{b}} \pm 0.34$ & $21.19^{\mathrm{a}} \pm 0.34$ \\
\hline $\mathrm{IDF}^{* *}$ & $10.21^{\mathrm{e}} \pm 0.52$ & $11.10^{\mathrm{d}} \pm 0.32$ & $14.14^{\mathrm{c}} \pm 0.08$ & $16.16^{\mathrm{b}} \pm 0.30$ & $19.34^{\mathrm{a}} \pm 0.30$ \\
\hline $\mathrm{SDF}^{* * *}$ & $1.40^{\mathrm{d}} \pm 0.06$ & $1.62^{\mathrm{c}} \pm 0.01$ & $1.69^{\mathrm{bc}} \pm 0.03$ & $1.77^{\mathrm{ab}} \pm 0.03$ & $1.85^{\mathrm{a}} \pm 0.06$ \\
\hline Ash & $1.11^{\mathrm{c}} \pm 0.08$ & $1.41^{\mathrm{b}} \pm 0.12$ & $1.35^{\mathrm{b}} \pm 0.09$ & $1.51^{\mathrm{ab}} \pm 0.07$ & $1.63^{\mathrm{a}} \pm 0.09$ \\
\hline Carbohydrates & $62.99^{\mathrm{a}} \pm 0.06$ & $57.00^{\mathrm{b}} \pm 0.06$ & $51.70^{\mathrm{c}} \pm 0.07$ & $48.32^{\mathrm{d}} \pm 0.03$ & $43.24^{\mathrm{e}} \pm 0.04$ \\
\hline Total calories (kcal) & $344.96^{\mathrm{a}} \pm 3.07$ & $333.98^{\mathrm{b}} \pm 1.64$ & $327.42^{\mathrm{c}}+1.39$ & $321.14^{\mathrm{d}} \pm 1.29$ & $312.48^{\mathrm{e}} \pm 1.64$ \\
\hline
\end{tabular}

Means in the rows, followed by equal letters, do not differ from one another at the level of $5 \%$ of significance by the Tukey test. *total dietary fiber; $* *$ insoluble dietary fiber; $* * *$ soluble dietary fiber

Ciênc. agrotec., Lavras, v. 36, n. 3, p. 333-340, maio/jun., 2012 
Table 3 - Mean values of the mineral content of the food bars made with by-products (broken-rice, BR and pequi nut, PN) and waste (of the soybean extract, SER and the pineapple, PW) of agroindustries, with fixed amounts of PN and PW and different BR:SER proportions.

\begin{tabular}{ccccccc}
\hline $\begin{array}{c}\text { Minerals } \\
\left(\mathrm{mg} .100 \mathrm{~g}^{-1}\right)\end{array}$ & $1: 0(\mathrm{~A})$ & $3: 1(\mathrm{~B})$ & $1: 1(\mathrm{C})$ & $1: 3(\mathrm{D})$ & $0: 1(\mathrm{E})$ & DRI* $^{*}(\mathrm{mg} / \mathrm{dia})$ \\
\hline $\mathrm{P}$ & $175^{\mathrm{c}} \pm 19.14$ & $200^{\mathrm{bc}} \pm 18.25$ & $227.5^{\mathrm{b}} \pm 15.00$ & $222.5^{\mathrm{b}} \pm 22.17$ & $275^{\mathrm{a}} \pm 19.14$ & 580 \\
$\mathrm{~K}$ & $242.5^{\mathrm{c}} \pm 22.17$ & $300^{\mathrm{c}} \pm 35.59$ & $330^{\mathrm{bc}} \pm 8.16$ & $392.5^{\mathrm{b}} \pm 0.21$ & $495^{\mathrm{a}} \pm 26.30$ & 4.700 \\
$\mathrm{Mg}$ & $97.5^{\mathrm{d}} \pm 5.00$ & $117.5^{\mathrm{c}} \pm 9.57$ & $137.5^{\mathrm{b}} \pm 9.57$ & $137.5^{\mathrm{b}} \pm 9.57$ & $170^{\mathrm{a}} \pm 8.16$ & 350 \\
$\mathrm{~S}$ & $127.5^{\mathrm{c}} \pm 18.92$ & $137.5^{\mathrm{bc}} \pm 17.07$ & $152.5^{\mathrm{abc}} \pm 12.58$ & $165^{\mathrm{ab}} \pm 10.00$ & $182.5^{\mathrm{a}} \pm 9.57$ & - \\
$\mathrm{Cu}$ & $0.53^{\mathrm{d}} \pm 0.03$ & $0.65^{\mathrm{c}} \pm 0.02$ & $0.76^{\mathrm{b}} \pm 0.02$ & $0.86^{\mathrm{a}} \pm 0.03$ & $0.91^{\mathrm{a}} \pm 0.05$ & 0.7 \\
$\mathrm{Mn}$ & $1.45^{\mathrm{a}} \pm 0.11$ & $1.40^{\mathrm{a}} \pm 0.03$ & $1.45^{\mathrm{a}} \pm 0.02$ & $1.56^{\mathrm{a}} \pm 0.09$ & $1.56^{\mathrm{a}} \pm 0.08$ & 2.3 \\
Zn & $1.69^{\mathrm{b}} \pm 0.12$ & $1.89^{\mathrm{b}} \pm 0.10$ & $1.83^{\mathrm{b}} \pm 0.15$ & $2.38^{\mathrm{a}} \pm 0.38$ & $2.11^{\mathrm{ab}} \pm 0.13$ & 9.4 \\
Fé & $3.57^{\mathrm{c}} \pm 0.46$ & $3.33^{\mathrm{c}} \pm 0.23$ & $3.98^{\mathrm{bc}} \pm 0.30$ & $4.62^{\mathrm{b}} \pm 0.18$ & $5.58^{\mathrm{a}} \pm 0.73$ & 6 \\
\hline
\end{tabular}

Means in the columns followed by equal letters do not differ from one another at 0.05 of significance by the Tukey's test $\mathrm{BR}=$ broken rice; $\mathrm{SER}=$ soybean extract residue.

* Dietary Reference Intake (DRI) for adults in Adequate Intake, AI (K and Mn) and Estimated Average Requirement, EAR fro the others (IOM, 2005).

The intake of one food bar unit $(25 \mathrm{~g})$ meets from 18.9 (A) to $32.5 \%$ (E) of the EAR of copper established per day for an adult (IOM, 2005)

The total iron present in a food bar $(25 \mathrm{~g})$ meets from $14 \%$ (B) to $23 \%$ (treatment E) of the EAR of iron established for male adults.

The average minerals values of the different proportions of BR and SER among the solid components of the food bars are close to the contents presented by Fernandes et al. (2000), in studies of chemical characterization of dehydrated hydrosoluble extracts of rice and soybean, who also evidenced the increased values as the soybean was increased and rice decreased.

\section{Chemical scores of the food bars}

The chemical score of the food bars made with byproducts and agroindustrial waste (Table 4) points out that the formulations contain all the essential aminoacids, but in some treatments (A, B), they do not reach the recommended levels.

It was found that the increase of the SER proportions and the decrease of BR resulted in a growing increase in the contents of essential aminoacids, mainly lysine, which is an essential limiting aminoacid in rice and present in soybean in great amounts. However, for the sulphurcontaining aminoacids (methionine and cysteine) and triptophane, no increases were found. However, those aminoacids proved representative in relation to the $\mathrm{FAO} /$ WHO standard (1990), a fact which was not expected at all, since soybean is poor in sulfur-containing aminoacids, which likely can have been supplied by the dry component PN which presents high protein content.

Treatments D and E stood out as the only ones which presented a profile of all the excess essential aminoacids in relation to the FAO/WHO (1990) references. Those results corroborate with the study by Bakar and Hin (1984) in which high protein value breakfast cereal with mixture of soybean and rice was developed and concluded that there must be at least $20 \%$ soybean incorporation into the product.

Treatments A and B presented both lysine (primary) and threonine (secondary) as limiting aminoacids; and lysine was the limiting aminoacid in treatment C (12\% BR with $12 \%$ SER).

Therefore, efforts to optimize the aminoacid balance with plant protein sources should deserve considerable attention (TIRAPEGUI et al., 2007) as interesting products for the protein intake of human beings.

\section{Physicochemical characteristics of food bars}

Table 5 shows the values of $\mathrm{pH}$, soluble solids and water activity of food bars.

The $\mathrm{pH}$ values of the food bars were relatively low, pointing out a slightly acidic product and minimum $\mathrm{pH}$ for the development of a wide variety of pathogenic microorganisms. The $\mathrm{pH}$ of the food bars reduced as the proportion of SER increased and that of BR decreased, but the acidic medium prevailed in all the treatments. 
Table 4-Chemical score (\%) of the proteins of the food bars made with by-products (broken rice, BR and pequi nut, $\mathrm{PN}$ ) and waste (from the soybean extract, SER and from the pineapple, PW) of the agroindustries, with fixed amounts of PN and PW and different BR:SER proportions .

\begin{tabular}{|c|c|c|c|c|c|}
\hline \multirow[t]{2}{*}{ Aminoacids } & \multicolumn{5}{|c|}{ Chemical score $(\%)$} \\
\hline & $1: 0(\mathrm{~A})$ & $3: 1(\mathrm{~B})$ & $1: 1(\mathrm{C})$ & $1: 3(\mathrm{D})$ & $0: 1(\mathrm{E})$ \\
\hline Valine & 134.09 & 151.51 & 148.37 & 139.97 & 135.91 \\
\hline Isoleucine & 128.93 & 148.82 & 147.43 & 143.57 & 146.71 \\
\hline Leucine & 114.86 & 120.53 & 115.00 & 118.02 & 117.94 \\
\hline Lysine & 62.24 & 71.84 & 96.41 & 101.78 & 102.52 \\
\hline Met+Cys* & 127.64 & 128.76 & 101.20 & 110.56 & 109.76 \\
\hline Phe+Tyr** & 114.62 & 114.24 & 118.35 & 115.67 & 126.98 \\
\hline Threonine & 90.24 & 94.71 & 101.82 & 114.53 & 111.29 \\
\hline Triptophane & 196.91 & 223.82 & 169.45 & 159.91 & 156.73 \\
\hline Histidine & 142.47 & 139.58 & 210.26 & 168.21 & 153.63 \\
\hline
\end{tabular}

* Methionine+Cysteine.

** Phenylalanine+Tyrosine.

Table 5 - Average values of physicochemical characteristics of the food bars made with by-products and agroindustrial waste with different BR:SER proportions, in the dry components.

\begin{tabular}{cccc}
\hline Food bars (BR:SER) & $\mathrm{pH}$ & Soluble solids $\left({ }^{\circ}\right.$ Brix $)$ & Water activity (Aw) \\
\hline $1: 0(\mathrm{~A})$ & $4.58^{\mathrm{c}} \pm 0.04$ & $55^{\mathrm{c}} \pm 0.00$ & $0.590^{\mathrm{a}} \pm 0.00$ \\
$3: 1(\mathrm{~B})$ & $4.80^{\mathrm{b}} \pm 0.05$ & $55^{\mathrm{c}} \pm 0.00$ & $0.580^{\mathrm{ab}} \pm 0.00$ \\
$1: 1(\mathrm{C})$ & $4.87^{\mathrm{b}} \pm 0.01$ & $60^{\mathrm{b}} \pm 0.00$ & $0.578^{\mathrm{bc}} \pm 0.00$ \\
$1: 3(\mathrm{D})$ & $4.88^{\mathrm{b}} \pm 0.02$ & $60^{\mathrm{b}} \pm 0.00$ & $0.572^{\mathrm{c}} \pm 0.00$ \\
$0: 1(\mathrm{E})$ & $4.98^{\mathrm{a}} \pm 0.05$ & $65^{\mathrm{a}} \pm 0.00$ & $0.550^{\mathrm{d}} \pm 0.00$ \\
\hline
\end{tabular}

Means in the columns followed by equal letters do not differ from one another at 0.05 of significance by Tukey's test.

Increase of the Brix degree of the food bars occurred as the proportion of the SER rose and that of BR reduced. The rise of $\mathrm{pH}$ found between treatments A and E likely influenced the result of the soluble solids of the food bars, since the proteins which constitute them, on moving away from their respective isoelectric points, present increased solubility (SGARBIERI, 1987).

All the treatments presented $A_{w}$ with values bellow 0.60 , indicating food safety. For any sort of bacteria, the minimum Aw value required for growth is of 0.75 , while osmophilic yeasts and xerophillic fungi are capable to develop in $\mathrm{A}_{\mathrm{w}}$ of 0.61 and 0.65 , respectively (SILVA, 2000; EVANGELISTA, 2005).

The confectionary products with high sugar contents present poor water activity, being generally microbiologically stable (BRASILEIRA DE EQUIPAMENTOS - BRASEQ, 2006).

\section{CONCLUSIONS}

The utilization of by-products and agroindustrial waste in the making of food bars, mainly for the formulations with greatest proportions of soybean extract waste (treatments D and E) is viable, for these stood out in both protein amount and quality, dietary fiber and of the majority of minerals, however, it furnished food bars with less caloric value.

All the types of food bars made were considered sources of dietary fiber.

\section{ACKNOWLEDGEMENTS}

The authors thank the Conselho Nacional de Desenvolvimento Científico e Tecnológico, CNPq (National Council for Scientific and Technological Development CNPq) and Fundação de Amparo à Pesquisa de Minas 
Gerais, FAPEMIG (Minas Gerais Support Foundation) for the financial support for the accomplishment of this work.

\section{REFERENCES}

AGÊNCIA NACIONALDE VIGILÂNCIA SANITÁRIAANVISA. Portaria n ${ }^{\circ} 27$, de 13 de janeiro de 1998. Regulamento referente à informação nutricional complementar (declarações relacionadas ao conteúdo de nutrientes). Diário Oficial da União, Brasília.

\section{ASSOCIATION OF OFFICIALANALYTICAL} CHEMISTS - AOAC. Official methods of analytical of the Association of Official Analytical Chemists. 15.ed. Washington, 1990. v.2.

\section{ASSOCIATION OF OFFICIALANALYTICAL} CHEMISTS - AOAC. Official methods of analytical of the Association of Official Analytical Chemists. 16.ed. Washington, 1997. v.1/2. (Methods 960.52, 985,29).

BAKAR, J.; HIN, Y.S. High-protein rice-soua breakfast cereal. Journal of Food Processing and Preservation, Westport, v.8, n.3-4, p.163-174, Nov. 1984.

BALESTRO, E.A.; SANDRI, I. G; FONTANA, R. C. Utilização de bagaço de uva com atividade antioxidante na formulação de barra de cereais. Revista Brasileira de Produtos Agroindustriais, Campina Grande, v.13, n.2, p.195-201, 2011.

BAÚ, T. R. et al. Barra alimentícia com elevado valor proteíco: formulação, caracterização e avaliação sensorial. Revista Brasileira de Tecnologia Agroindustrial, Ponta Grossa, v.4, n.1, p. 42-51, 2010.

BORGES, C.D. et al. Produção de suco de abacaxi obtido a partir dos resíduos da indústria conserveira. Boletim CEPPA, Curitiba, v.22, n.1, p.25-34, jan./jun. 2004.

BOTELHO,L.; CONCEIÇÃO, A.; CARVALHO, V.D. Caracterização de fibras alimentares da casca e cilindro central do abacaxi "smooth cayenne". Ciência e Agrotecnologia, Lavras, v.26, n.2, p.362-367, mar./abr. 2002.

BRASILEIRA DE EQUIPAMENTOS - BRASEQ.

Entendendo a atividade de água (Aw) e sua importância para a qualidade de alimentos e outros produtos em geral. Boletim Técnico Informativo. Jarinu, SP, 2006. 10p.
BRASIL, Resolução RDC no 263, de 22 de setembro de 2005, Agência Nacional De Vigilância Sanitária - Anvisa; Aprova O "Regulamento Técnico Para Produtos De Cereais, Amidos, Farinhas E Farelos", Diário Oficial da União, Brasília (DF), de 23 de setembro de 2005.

EVANGELISTA, J. Tecnologia de alimentos. 2.ed. São Paulo: Atheneu, 2005. 652p.

FERNANDES, S.M. et al. Caracterização química de extratos hidrossolúveis desidratados de arroz e soja. Pesquisa Agropecuária Brasileira, Brasília, v.35, n.4, p. 843-847, abr. 2000.

\section{FOOD AND AGRICULTURE ORGANIZATION - FAO/ WHO. World Health Organization. Protein quality evaluation: report of a joint $\mathrm{FAO} / \mathrm{WHO}$ expert consultation. Roma, 1990.}

FREITAS, D.G.C.F.; MORETTI, R.H. Caracterização e avaliação sensorial de barras de cereais funcional de alto teor protéico e vitamínico. Ciência e Tecnologia de Alimentos, Campinas, v.26, n.2, p. 318-324, abr./jun. 2006.

FREITAS, D.G.C.F.; MORETTI, R.H. Barras de cereais elaboradas com proteína de soja e gérmem de trigo, características físico-químicas e textura durante armazenamento. Archivos Latinoamaricanos de Nutrición, Caracas, v.55, n.3, set. 2005.

GIUNTINI, E.B.; LAJOLO, F.M.; MENEZES, E.W. Potencial de fibra alimentar em países ibero-americanos: alimentos, produtos e resíduos. Archivos

Latinoamaricanos de Nutrición, Caracas, v.53, n.1, p.17, mar. 2003.

GOMES, C.R.; MONTENEGRO, F.M. Curso de tecnologia de barras de cereais. Campinas: ITAL, 2006.

INSTITUTE OF MEDICINE - IOM,. Dietary reference intakes for energy. Washington: National Academy, 2005. 1331p.

LUCAS, B.; SOTELO, A. Effect of different alkalis, temperatures and hydrolyses times on tryptophan determination of pure proteins and foods. Analytical Biochemistry, New York, v.109, n.1, p.192-197, 1980.

MAIA, L. H. et al. Características químicas dos mingaus desidratados de arroz e soja. Ciência e Tecnologia de Alimentos, Campinas, v.20, n.3, p.416-423, set/dez, 2000. 
MALAVOLTA, E.; VITTI, G.C.; OLIVEIRA, S.A. Avaliação de estudo nutricional de plantas. Piracicaba: Potafos, 1989. 201p.

MITCHELL, V.W.; BOUSTAIN, P. Cereal bars: a perceptual, chemical and sensory analysis. British Food Journal, v.92, n.5, p.17-22, 1990.

OSBORNE, D. R.; VOOGT, P. The analysis of nutrient in foods. London: Academic Press, 1978. 251 p.

PELLET, P.L.; YOUNG V.R. Nutritional evaluation of protein foods. Tokyo: The United Nations University, 1980. 154p.

PENNA, E.W.; TUDESCA, M.V. Desarrollo de alimentos. In: LAJOLO, F.M. In: LAJOLO, F.M. et al. Fibra dietética en iberoamérica: tecnología y salud, obtención, caracterización, efecto fisiológico y aplicación en alimentos. São Paulo: Varela, 2001. cap.17, p.245-265.

PROSKY, L. et al. Determination of insoluble, soluble and total dietary fibre in foods and food products. Interlaboratory study. Journal of the Association of Official Analytical Chemistry, v.71, p.1017-1023, 1998.
SGARBIERI, V.C. Alimentação e nutrição: fator de saúde e desenvolvimento. São Paulo: Almed, 1987. 387p.

SILVA, J.A. Tópicos da tecnologia de alimentos. São Paulo: Livraria Varela, 2000. p.227.

SOUZA, O.; SANTOS, I.E. Importância dos resíduos agropecuários na alimentação animal. Boletim Pecuário, 2002. Disponível em: http://www.boletimpecuario.com.br/ artigos/showartigo.php?arquivo=artigo544.txt. Acesso em: 24 out. 2006.

SPACKMAN, D.H.; STEIN, W.H.; MOORE, S. Automatic recording apparatus for use in the chromatography of amino acid. Analytical Chemistry, Easton, v.30, n.7, p.1190-1206, 1958.

TETTWEILER, P. Snack food worldwide. Food Technology, Beltsville, v.45, p.58-62, 1991.

TIRAPEGUI, J.; CASTRO, I.A.; ROSSI, L. Biodisponibilidade de proteínas. In: COZZOLINO,

S.M.F. Biodisponibilidade de nutrientes. 2.ed.atua.ampl. Barueri, SP: Manole, 2007. p.67-123. 